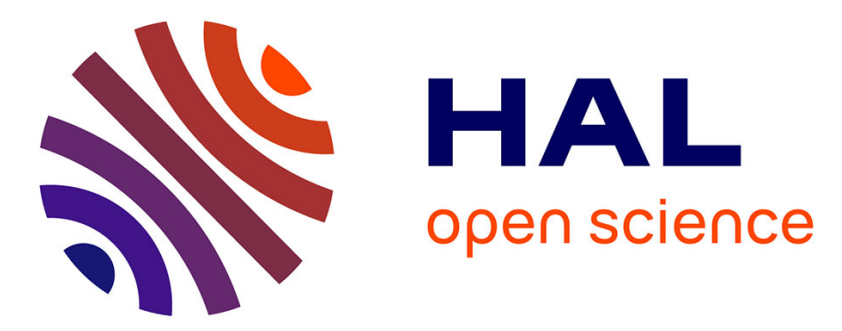

\title{
Research on Irrigation System of Limited Water Supply for Soybean Crops in Shanxi Province
}

\author{
Lantao Ye, Yangren Wang, Qing Liu, Sida Wang
}

\section{To cite this version:}

Lantao Ye, Yangren Wang, Qing Liu, Sida Wang. Research on Irrigation System of Limited Water Supply for Soybean Crops in Shanxi Province. 11th International Conference on Computer and Computing Technologies in Agriculture (CCTA), Aug 2017, Jilin, China. pp.263-270, 10.1007/978-3030-06179-1_27. hal-02111528

\section{HAL Id: hal-02111528 \\ https://hal.inria.fr/hal-02111528}

Submitted on 26 Apr 2019

HAL is a multi-disciplinary open access archive for the deposit and dissemination of scientific research documents, whether they are published or not. The documents may come from teaching and research institutions in France or abroad, or from public or private research centers.
L'archive ouverte pluridisciplinaire HAL, est destinée au dépôt et à la diffusion de documents scientifiques de niveau recherche, publiés ou non, émanant des établissements d'enseignement et de recherche français ou étrangers, des laboratoires publics ou privés. 


\title{
Research on irrigation system of limited water supply for soybean crops in Shanxi Province
}

\author{
Lantao YE ${ }^{1,2(\bowtie)}$, Yangren WANG ${ }^{1,2}$, Qing LIU ${ }^{1}$, and Sida WANG ${ }^{1}$ \\ ${ }^{1}$ Department of Hydraulis Engineering,Tianjin Agricultural University,Tianjin 300384,China \\ ${ }^{2}$ Tianjin Agricultural Water Conservancy Technology Engineering Center \\ yltao1982@126.com
}

\begin{abstract}
The limited water supply irrigation system for soybean crops in Shanxi Province was studied.The irrigation data of Limin experimental station in Linfen City, Shanxi Province had been selected.Frequency calculation of rainfall data of Limin was made,choosing 2010, 1993 and 1997 respectively as the sample year of plain water year $(50 \%)$, water year dry year $(75 \%)$ and special drought year (95\%) of Limin. The Jensen model as the basis for calculation was selected,calculating the actual yield value of crop according to the actual crop water requirement 、crop maximum water demand sensitive index value and maximum crop yield at each stage.Through the selection of the number of days of irrigation,the optimization model of irrigation times was established.The limiting condition is the maximum actual yield.The quota irrigation system of soybean crops in different hydrological years was determined.According to calculation results,each target year was three times, with the highest amount of water.
\end{abstract}

Keywords:Irrigationsystem;Quota water supply;ShanxiProvince;Soybean crops

\section{Introduction}

With the continuous progress of human society, the level of scientific and technological production continues to develop,our demand for water is increasing and the range of use will become more and more extensive.Agricultural irrigation is no longer simple irrigation of crops, and how to carry out effective and reasonable scientific irrigation has become the consensus of people.Under the premise of the serious shortage of water resources, agricultural irrigation is difficult to make adequate supply of water needed for every stages of crops growthy, so the optimal utilization of irrigation water resources becomes more and more important.In the case of water shortages and insufficient water supply, the irrigation water is optimized at different stages of the crop to optimize the irrigation allocation, so as to obtain higher irrigation benefits and achieve the goal of increasing production in this way.

Linear programming, referred to as LP[1,2], helps us to study linear constraints, as well as to understand some of the related objective functions.XiaoSujun et [3-5] started from the actual water sensitivity index and the water production function of a part of irrigation areas in the Yellow River.They pointed out the main irrigation time of all kinds of crops and Got the irrigation system under the condition of quota of water supply in irrigated area.Qiu Lin et [6-8] gave the irrigation system with a multi- 
level innovation model that contains the risk index of crop planting which not only reduces the risk of planting, but also reduces the amount of water used for irrigation.Based on the viewpoint of non sufficient irrigation, Wang Zhiliang et [9-11] provided a irrigation system suitable for single crop in irrigation area and a dynamic programming model.They set up models to analyze the combined use of various water resources, and in the model to reflect the first use of surface water facts.According to the advantages of the accelerated genetic algorithm (RAGA) and the multidimensional dynamic programming (DP) method, the genetic dynamic programming model (RA GA DP) was given by Fu Qiang et $[12,13]$.which is helpful to eliminate the premature precocity in the improvement of irrigation system, and to emphasize local optimization and not easy to get the most suitable.CuiYuanlai $[14,15]$ had analyzed the actual water production function of the crops and concluded that the net irrigation of crops during different growth periods was best suited to the deployment by means of SDP, getting an effective irrigation system for a single crop.

We should provide adequate water supply during the growth period where the crops need water for the most part.The specific time of yield increase is given when the irrigation critical water is obtained, and the crop yield under different irrigation levels is estimated in every target years of water. Determine how much water is used to determine yield, and then to opt imize the irrigation system of crops.To promote the limited water resources to the maximum benefit in order to achieve the goal of watersaving irrigation. According to the different factors of different crops, we have made a suitable irrigation system, which has a remarkable effect on agricultural water saving.Therefore, it is significant to study the irrigation system of crop quota water supply.

\section{$2 \quad$ Materials and methods}

\subsection{Selection of soybean experiment}

Through the experiment data of soybean in Shanxi province, the main experimental sites of soybean crops were distributed in the Hutuo River、Central Experimental Station、Wenyuhe、 Licheng、Linfen、Huoquan and Limin.This study choosed the data of the Limin experimental station in the Linfen city of Shanxi Province to study the quota irrigation system.

\subsection{Test processing design}

According to the situation of rainfall and crop water requirement in the Limin test station in Shanxi Province, five treatments were designed according to the plan of the provincial hall.The area area was $34.8 \mathrm{~m}^{2}$.

\subsection{Field operation management}

Using the local field cultivation and management measures, tested varieties was Fen bean 17, sowing rate was $10 \mathrm{~kg} / \mathrm{mu}$, it was fertilizersapplied Yunnan phosphate fertilizer of $40 \mathrm{~kg} / \mathrm{mu}$. During intertill 3 times, the depth was 5 to 7 centimeters.

\subsection{Meteorological conditions of soybean}

The average temperature of soybean was 20.6 degrees in growth period;the total rainfall was $216.4 \mathrm{~mm}$, effective rainfall was $201.5 \mathrm{~mm}$;belonging to plain water year, water surface evaporation $(20 \mathrm{~cm}$ diameter) was $549 \mathrm{~mm}$; sunshine hours was 500.1 hours; the relative humidity was $76 \%$; natural disasters did not occur . 


\subsection{Soil moisture determination}

Soil moisture was determined by soil drilling and soil drying method. The soil depth was $140 \mathrm{~cm},(0-20 \mathrm{~cm}, 20-40 \mathrm{~cm}, 40-60 \mathrm{~cm}, 60-80 \mathrm{~cm}, 80-100 \mathrm{~cm}, 100-120 \mathrm{~cm}, 120-$ $140 \mathrm{~cm}$ ), which was measured in seven layers. Soil moisture was measured every ten days during the growth period of soybean:on the 1st, 11th and 21 st days of each month at the beginning of the growth stage and after precipitation.

\subsection{Irrigation situation}

In the test, the water well irrigation、 water meter measurement water quantity and the field irrigation water delivery system were adopted.The semi fixed plastic pipeline was used to transport water, and the water outlet pipe was connected with the hose for irrigation.

\subsection{Field observation survey}

At the growth stage of soybean, plant growth was observed, and yield structure were determined after harvest.

\subsection{Basic parameters}

According to historical data, the soybean irrigation quota was $50 \mathrm{~mm}$. In recent years, the maximum yield per mu of soybeans was $175 \mathrm{~kg} / \mathrm{mu}$. The soil basic parameters soybean stages crop coefficients and soybean growth period are shown in Table 1 and table 2 .

Table 1. Soil basic parameters of test station

\begin{tabular}{cccccc}
\hline & Volume weight & Soil & Field moisture & wilting percentage & Initial rate \\
Area & of soil & capacity (percent & (percent by & of water \\
& $\left(\mathrm{g} / \mathrm{m}^{3}\right)$ & depth $(\mathrm{m})$ & by weight $)$ & weight $)$ & content \\
\hline Limin & 1.46 & 0.5 & 24.6 & 6 & 19.2 \\
\hline
\end{tabular}

Table 2. Observation record of soybean growth period

\begin{tabular}{cccccccc}
\hline Area & Year & Sow & Branch & Bloom & Pod & Seed-filling & Harvest \\
\hline Limin & 2008 & 5.19 & 7.2 & 7.12 & 7.22 & 8.12 & 9.12 \\
\hline
\end{tabular}

\section{Formulation of soybean quota irrigation system}

\subsection{Frequency calculation}

Irrigation design reliability is that the probability of irrigation water consumption can be fully satisfied over the yearsin the irrigation area,generally expressed by the percentage of years which design irrigation water is fully satisfied in total computed years.Formula see form (1).

$$
P=\frac{\mathrm{m}}{\mathrm{n}+1} \times 100 \%
$$

Formula: $\mathrm{P}$ is the guarantee rate of irrigation design; $\mathrm{m}$ is to calculate the number of 
years when the water supply is greater than or equal to the irrigation water requirement; $n$ is the total number of

years for the calculation series, in large and medium-sized irrigation areas, the calendar year should not be less than 30 years.

Based on the analysis of precipitation frequency table in Linfen city of Shanxi Province, the meteorological data of three typical hydrological years in $2010(50 \%)$, $1993(75 \%)$ and 1997 (95\%) were selected as the basis for the study of the quota irrigation system.

\subsection{Calculation of crop water requirement}

In the study, the method of calculating the actual crop water requirement was adopted by reference to the water requirement.

crop coefficient KcCrop coefficient can be divided into four stages: initial growth stage, rapid growth stage, middle fertility stage and mature stage. By referring to the crop coefficient recommended by FAO, the coefficient of soybean crop in Limin area is shown in table 3 .

Table 3. Coefficient of soybean fractional crop

\begin{tabular}{ccccccc}
\hline \multirow{2}{*}{ Area } & Growth & Initial & Redium & Full growth & Whole \\
& stage & growth & maturity & growth \\
stage & growth stage & stage & period \\
\hline \multirow{2}{*}{ Limin } & Crop & & & & & \\
& coefficient & 0.67 & $0.67 \sim 1.09$ & 1.09 & $1.09 \sim 0.48$ & \\
& Days & 20 & 30 & 40 & 27 & 117 \\
\hline
\end{tabular}

Soil moisture correction coefficientThe model proposed by Lei Zhidong et al. (1988), see form (2).

$$
K_{s}=\left\{\begin{array}{cc}
1 & \theta \geq \theta_{j} \\
a+b \theta & \theta \leq \theta_{j} \\
0 & \theta \leq \theta_{w p}
\end{array}\right.
$$

$\theta_{\text {is the actual water content of soil root layer; }} \theta_{w p}$ is permanent wilting point moisture content. $\theta_{j}$ is critical moisture content

Actual crop evapotranspirationMeteorological factors, crop factors and soil factors should be taken into consideration in actual crop water requirements. Its formula is formula 3 .

$$
E T=K_{s} K_{c} E T_{0}
$$

In the formula, ET is the actual crop evapotranspiration; ET0 is the reference crop evapotranspiration; $\mathrm{Kc}$ is the crop coefficient; $\mathrm{Ks}$ is the soil water correction coefficient.

\subsection{Determination of crop water production function}

Crop water production function is a mathematical model which reflects the variation of crop yield and water content, and is the basic theoretical basis for irrigation 
planning , design and management of non sufficient irrigation. Jensen model is a static model of water production function, referred to as the multiplicative model, widely used in recent years. The expressions for the Jensen model are present in Eq. (4).

$$
\frac{y}{y_{m}}=\prod_{i=1}^{n}\left(\frac{E T}{E T_{m i}}\right)_{i}^{\lambda_{i}}
$$

In formula: $n$ is the number of stages of crop fertility; $i$ is the number of the crop stages; $\mathrm{Y}$ is the actual yield of crops $(\mathrm{kg} / \mathrm{hm} 2)$; $\mathrm{Ym}$ is the maximum yield $(\mathrm{kg} / \mathrm{hm} 2)$ for full irrigation. ETi is the actual evapotranspiration in i growth stage (mm); ETmi and Ym corresponding to the $\mathrm{i}$ evapotranspiration growth stage $(\mathrm{mm}) ; \lambda \mathrm{i}$ is a sensitive index in lambda $\mathrm{i}$ growth stage, reflecting the influence on output stage water shortage degree, and it is an important parameter in the model.

Selection of sensitivity indexAccording to the experimental data of Jensen model, the sensitive index of the growth stages of soybean crops was calculated,shown in table 4 .

Table4. Sensitive index tables of different growth stages of soybean

\begin{tabular}{|c|c|c|c|c|c|c|c|}
\hline Area & Year & Growth period & $\begin{array}{l}\text { Sowing } \\
\text { branching }\end{array}$ & $\begin{array}{l}\text { Branches - } \\
\text { flowering }\end{array}$ & $\begin{array}{l}\text { Flowering- } \\
\text { podding }\end{array}$ & $\begin{array}{l}\text { Podding- } \\
\text { Seed- } \\
\text { filling }\end{array}$ & $\begin{array}{l}\text { Seed- } \\
\text { filling- } \\
\text { mature }\end{array}$ \\
\hline \multirow{2}{*}{ Limin } & \multirow{2}{*}{2009} & & 0.0182 & 0.2527 & 0.1621 & 0.3292 & 0.2277 \\
\hline & & Cumulative days & 5 & 33 & 43 & 64 & 114 \\
\hline
\end{tabular}

Calculation of water production function at each growth stageEquation (3) shows that:

$$
\begin{aligned}
\frac{\mathrm{y}}{y_{m}} & =\left(\frac{E T}{E T_{m 1}}\right)^{\lambda_{1}} \times\left(\frac{E T}{E T_{m 2}}\right)^{\lambda_{2}} \times \Lambda \times\left(\frac{E T}{E T_{m n}}\right)^{\lambda_{n}} \\
\mathrm{y} & =\left(\frac{E T}{E T_{m 1}}\right)^{\lambda_{1}} \times\left(\frac{E T}{E T_{m 2}}\right)^{\lambda_{2}} \times \Lambda \times\left(\frac{E T}{E T_{m n}}\right)^{\lambda_{n}} \times \mathrm{y}_{\mathrm{m}}
\end{aligned}
$$

Through the formula 5, the actual crop yield Y can be obtained according to the actual crop water requirement、 crop maximum water demand sensitive index value and maximum crop yield at each stage.

According to the sensitivity index, the actual water requirement 、 the maximum water requirement at each stage and the water production function value of the 5 growing stages was calculated.

\subsection{Determination of irrigation time}

According to the research of irrigation on soybean irrigation system, the irrigation times were determined up to 3 times. So the limited irrigation system has three kinds of circumstances,choosing once, twice and three times watering in each plain water year, as the limit conditions was the actual maximum yield.

The pattern search method is adopted in this research to derive the maximum yield of crops. In the process of probing derive, according to the coordinate direction, the values are searched at a certain step size, when exploration results failed, step length is shrinked and searched again, until the search step length is less than the given accuracy. 
6

for soybean

crops has been worked out in different hydrological years, as shown in table 5 .

Table5. Soybean limited irrigation system

\begin{tabular}{|c|c|c|c|c|c|c|c|}
\hline $\begin{array}{c}\text { Hydrological } \\
\text { year type }\end{array}$ & $\begin{array}{l}\text { irrigation } \\
\text { frequency }\end{array}$ & $\begin{array}{l}\text { irrigation } \\
\text { quota }\end{array}$ & $\begin{array}{l}\text { irrigation } \\
\text { time }\end{array}$ & $\begin{array}{c}\mathrm{ET}_{\mathrm{m}} \\
(\mathrm{mm})\end{array}$ & $\begin{array}{c}\mathrm{ET}_{0} \\
(\mathrm{~mm})\end{array}$ & $\begin{array}{c}\mathrm{P} \\
(\mathrm{mm})\end{array}$ & $\begin{array}{c}(\mathrm{kg} / \mathrm{mu} \\
)\end{array}$ \\
\hline \multirow{3}{*}{$\begin{array}{l}50 \% \\
(2010)\end{array}$} & 1 & & 36 & & & & 114.41 \\
\hline & 2 & & $30 / 36$ & 372.11 & 416.12 & 246.3 & 141.43 \\
\hline & 3 & & $10 / 30 / 36$ & & & & 161.55 \\
\hline \multirow{3}{*}{$\begin{array}{l}75 \% \\
(1993)\end{array}$} & 1 & & 33 & & & & 133.71 \\
\hline & 2 & 50 & $16 / 33$ & 392.06 & 444.22 & 262.2 & 159.05 \\
\hline & 3 & & $1 / 16 / 33$ & & & & 170.80 \\
\hline \multirow{3}{*}{$\begin{array}{l}95 \% \\
(1997)\end{array}$} & 1 & & 31 & & & & 107.11 \\
\hline & 2 & & $22 / 31$ & 494.26 & 552.82 & 167.5 & 128.49 \\
\hline & 3 & & $22 / 31 / 52$ & & & & 141.95 \\
\hline
\end{tabular}

\section{Conclusion}

This study selected the irrigation data of Limin experimental station in Linfen city of Shanxi province, the irrigation system of limited water supply for soybean crops were studied in Shanxi province..Rainfall data were calculated at choosing 2010, 1993 and 1997 respectively as the sample year of plain water year $(50 \%)$, water year dry year $(75 \%)$ and special drought year $(95 \%)$ of Limin. The Jensen model were selected as the basis for calculation,calculating the actual yield value of crop according to the actual crop water requirement 、crop maximum water demand、sensitive index value and maximum crop yield at each stage.Through the selection of the number of days of irrigation,the optimization model of irrigation times were established. Every kinds of target years of water was respectively chosen to fill the water once, two times, and three times .The limiting condition is the maximum actual yield.The quota irrigation system of soybean crops in different hydrological years in Limin area was determined.According to calculation results, each target year was three times, with the highest amount of water.In actual irrigation, water shortage is often encountered and irrigation is required according to the limited water supply system. Therefore, it is necessary to analyze the irrigation system with limited water supply. The calculation results can provide the basis for the establishment of irrigation system for local crops.

\section{References}

1. Wang Yinen. Irrigation and drainage engineering [M]. China Water Conservancy and hydropower Press, (2014.8)

2. De Louw PGB, Eeman S, Essink GHP, Vermue E, Post VEA. Rainwater lens dynamics and mixing between infiltrating rainwater and upward saline groundwater seepage beneath a tile-drained agricultural field. Journal of Hydrology,501: 133-145(2013)

3. Cazcarro I,Hoekstra A Y,Choliz J S.The water footprint of tourism in Spain. Tourism Management, (40):90-101(2014) 
4. Yunfeng. Analysis of sprinkler irrigation system and economic benefit in eastern Inner Mongolia. Economic and technological markets, 87-88( 2016)

5. Zhu Ming, Sheina, Zhao. Study on optimal irrigation system for water-saving tomato crops in hetao irrigation area. Rural Water conservancy and hydropower in China, 64$68+72(2012)$

6. Wang Yinen, Wang Shaosheng, Zheng Zhiwei, Zhao Baoyong. Study on economic irrigation system of drip-irrigation eggplant under film in greenhouse. North Horticulture, 46-50 (2016)

7. Heydari M M,Heydari M.. Evaluation of pan coefficient equations for estimating reference crop evapotranspiration in the arid region.Archives of Agronomy And Soil Science, 715-731(2014)

8. Tao, Hu Rongxiang, Lu Cheng. Experimental study on the irrigation system of typical cash crops under the condition of Shannan spraying micro-irrigation. Zhejiang Water Conservancy Science and Technology, 18-20 (2014)

9. Xu Jianwei, Guo Yan, Han-Zhuo. Study on optimization of water-saving irrigation system for summer maize in Luoyang . People of the Yellow River, 75-76 (2012)

10.Zheng Jianhua. Water-saving response mechanism and irrigation system optimization simulation of economic crops in inland arid region of northwest China [D]. Chinese Agricultural University, (2014)

11.TARAQQI A K, 姬强, 王旭东. Impact of different tillage practices on soil organic carbon and water use efficiency under continuous wheat-maize binary cropping system. Chinese Journal of Applied Ecology, 1029-1035. (2014)

12. Garcia-Tejero IF,Arriaga J,Duran-Zuazo VH,Muriel-Fernandez JL.. Predicting crop-water production functions for long-term effects of deficit irrigation on citrus productivity (SW Spain). Archives of Agronomy And Soil Science,59(12): 1591-1606 (2013)

13. SONG Tong, CAI Huanjie, XU Jiatun. Water Requirement and Irrigation Schedule of Winter Wheat and Summer Maize in Jinghuiqu Irrigation District. Journal of Irrigation and Drainage, 52-56. (2017)

14. Azizian A, Sepaskhah A R.2.Maize response to different water,salinity and nitrogen levels: agronomic behavior.International Journal of Plant Production,8(1): 107-130 (2014)

15. Cammalleri C,Anderson M C,Gao F,Hain C R,Kustas W P.Mapping daily evapotranspiration at field scales over rainfed and irrigated agricultural areas using remote sensing data fusion. Agricultural and Forest Meteorology,186:1-11 (2014)

16. Hoff H,Doll P,Fader M,Gerten D,Hauser S, Siebert S.Water footprints of citiesindicators for sustainable consumption and production. Hydrology and Earth System Sciences, 18(1): 213-226 (2014) 